\title{
HYDROCHEMICAL ANALYSIS OF GROUND WATER OF RAMPURHAT-II BLOCK, BIRBHUM DISTRICT, WEST BENGAL, INDIA
}

\author{
Sakuntala Chakrabarti ${ }^{1, *}$ and Pulak Kumar Patra ${ }^{2}$ \\ ${ }^{1}$ Department of Environmental Science, Vivekananda College, \\ Kolkata-700063, West Bengal, India \\ ${ }^{2}$ Department of Environmental Studies, Visva Bharati, Birbhum-731235, West Bengal, India \\ *E- mail: sakuntala.vb@gmail.com
}

\begin{abstract}
The purpose of this study is investigating the chemical analysis of groundwater in Rampurhat-II block of Birbhum district,West Bengal, India. Altogether 24 representative groundwater Samples were collected from borewells and tubewells, during March 2010 in order to assess its suitability for drinking as well as irrigation purpose. The water chemistry of samples were analyzed for $\mathrm{pH}$, Total Dissolved Solids (TDS), Electrical Conductivity(EC), Sulphate $\left(\mathrm{SO}_{4}^{-2}\right)$, Nitrate $\left(\mathrm{NO}_{3}^{-}\right)$, phosphate $\left(\mathrm{PO}_{4}^{-3}\right)$, Fluoride $\left(\mathrm{F}^{-}\right)$, Calcium $\left(\mathrm{Ca}^{2+}\right)$, Magnesium $\left(\mathrm{Mg}^{2+}\right)$, Sodium $\left(\mathrm{Na}^{+}\right)$, Potassium $\left(\mathrm{K}^{+}\right)$, Bicarbonate $\left(\mathrm{HCO}_{3}^{-}\right)$, carbonate $\left(\mathrm{CO}_{3}{ }^{2-}\right)$, chloride $\left(\mathrm{Cl}^{-}\right)$and Total Hardness $(\mathrm{TH})$ using standard techniques.The results revealed that the maximum SAR (Sodium adsorption ratio) in the study area was 0.87 i.e, below 1. RSC (Residual sodium carbonate) value among the samples is maximum 0.844 which is below 1.25 meq/l, indicating no sodium carbonate hazard in the study area. \% Na values indicating its suitability for irrigation. But in most of the water samples some parameters like EC, $\mathrm{Ca}^{2+}, \mathrm{Na}^{+}$were above the acceptable limit recommended by WHO. pH ranged in all the samples within the limit (6.5 to 8.5). Based on the findings of this study, it can be expressed that the groundwater quality in Rampurhat-II block is suitable for irrigation but not appropriate for drinking as some of the parameters are elevated and need proper treatment. Although Birbhum district is one of the worst fluoride affected district in West Bengal the fluoride concentration was within the permissible limit i.e. 1.5 $\mathrm{mg} / \mathrm{l}$ in all samples.
\end{abstract}

Keywords:Groundwater quality, Rampurhat-II block, Birbhum district, West Bengal, India.

(c) RASĀYAN. All rights reserved

\section{INTRODUCTION}

The quality of water is vital for humankind. Some of the natural and anthropogenic processes are very important for modification of groundwater quality like oxidation/reduction, cation exchange, dissociation of minerals, precipitation of secondary minerals, mixing of waters, leaching of fertilizers and manure, pollution and lake/sea, biological processes. ${ }^{1}$ Poor quality of water adversely affects the human, animal and plant health. ${ }^{2-7}$ Groundwater quality data is essential to determine the origin of the chemical composition of groundwater. ${ }^{8}$ The Rampurhat II block under Birbhum district, West Bengal is predominantly a poor rural area with a significant tribal population. Agriculture is the main source of livelihood.Moreover, it lies in the semiarid zone of West Bengal. ${ }^{9}$ Thus groundwater quality mainly influenced by lithology and fertilizers used for agricultural purposes (leached with precipitation). The purpose of our present study is to study the groundwater quality of Rampurhat II block and to evaluate its suitability for drinking and irrigation.

\section{Study Area}

Rampurhat II is a rural area of Birbhum district, West Bengal, India. The coordinates are 24010'34' 'N $87^{0} 52^{\prime} 56^{\prime}$ 'E having an area of $184.22 \mathrm{Km}^{2}$. The groundwater samples were collected from Kabirajpur, Mountain, Dunigram and Modhupur villages. 
As per 2001 census, Rampurhat II block had a total population of 158,756, out of which 81,973 were males and 76,783 were females. The density of population is $862 / \mathrm{Km}^{2}$. The tribal population numbered 1081. During 1991 - 2001 decade population growth rate was $14.64 \%$.

Rampurhat II block climatologically falls under the western semi-arid belt of West Bengal. The summer is severe with an average temperature of $40^{\circ} \mathrm{C}$. During the month of May temperature shoots up to $48^{\circ} \mathrm{C}$. The average temperature is $10^{\circ} \mathrm{C}$ in winter, but temperature as low as $6^{\circ} \mathrm{C}$ is also recorded. This area receives rainfall from mid-June to September and sometimes up to October.

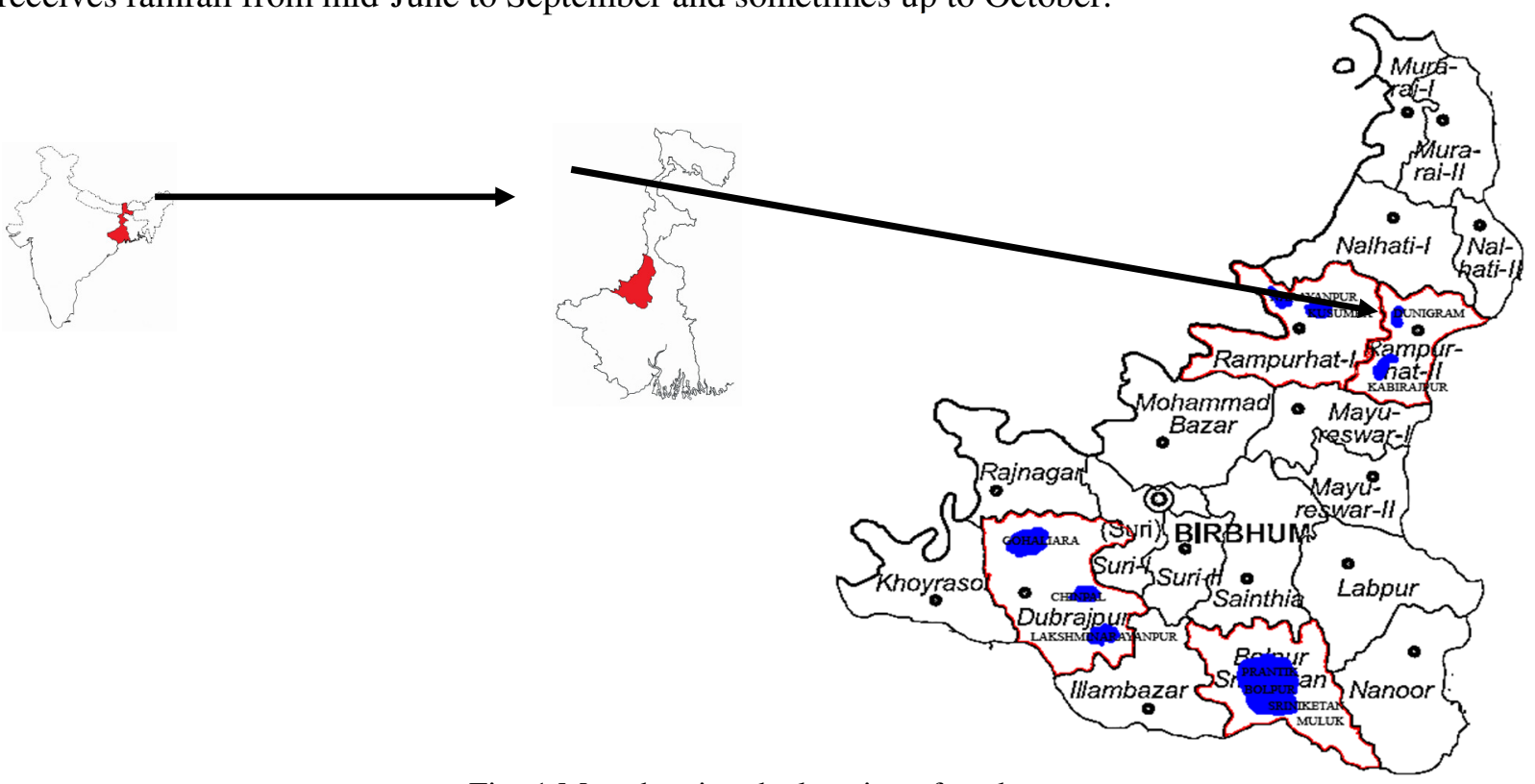

Fig.-1 Map showing the location of study area

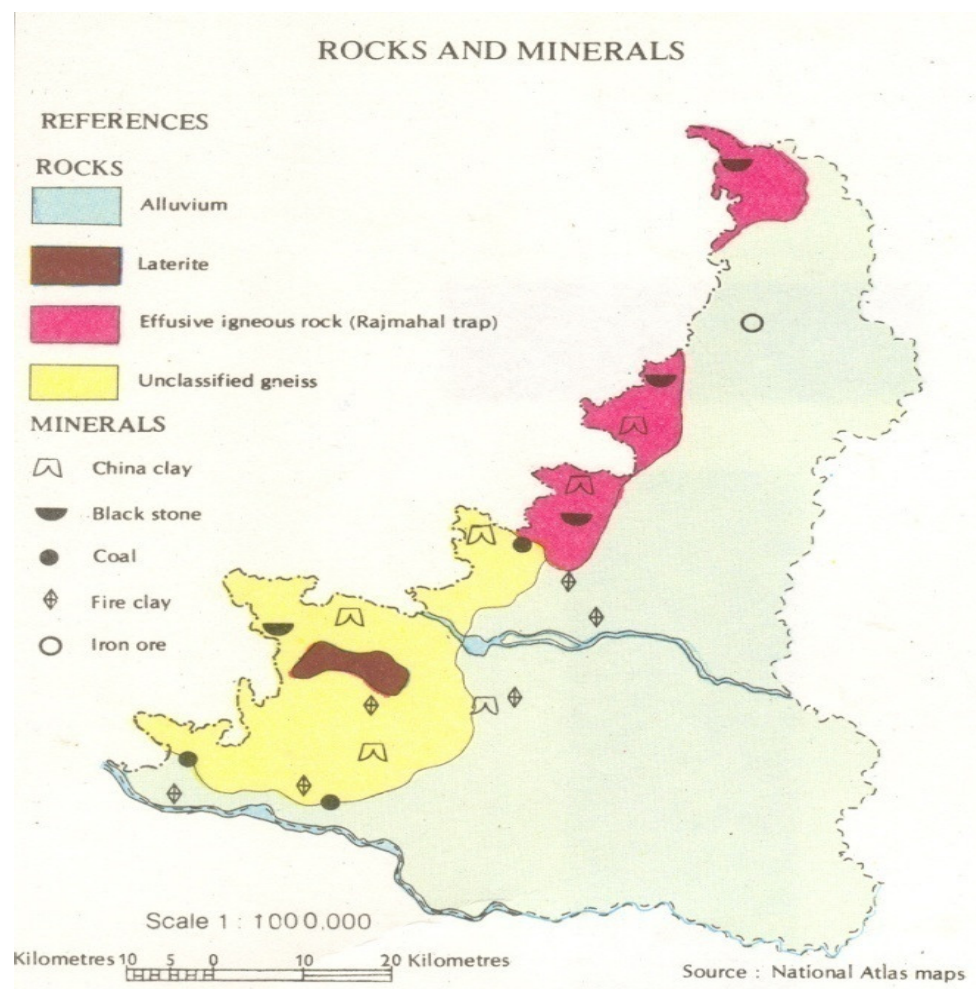

Fig.-2: Map showing the geology of the study area 


\section{Geology}

Geology of an area plays a very important role in the concentration of different chemical parameters of groundwater of an area. Rampurhat II block lies in the north east of Birbhum district. Mainly Gondwana overlay by Rajmahal trap (Basalt) occurring in the northern part of the district but some parts is occupied by Laterite. Rampurhat II is characterized by Older Alluvium (Rampurhat Formation).Hard clay impregnated with Caliche nodules of Rampurhat Formation in east and northeast of this district overlain by alternating layers of sand, silt, and clays of Kandi Formation of Quaternary age. In alluvial tracts (sand, silt, clay) the depth to water table in May-June is $2 \mathrm{~m}$ to $16 \mathrm{~m}$.

\section{EXPERIMENTAL}

From Rampurhat II block 19 tubewell and 5 borewell samples were collected from Kabirajpur, Mountain, Dunigram and Modhupur villages along with GPS during March, 2010. The parameters include Temperature, $\mathrm{pH}$, EC, Total hardness, TDS, cations like $\mathrm{Ca}^{2+}, \mathrm{Na}^{+}, \mathrm{K}^{+}, \mathrm{Mg}^{2+}$ and anions like $\mathrm{HCO}_{3}{ }^{-}$, $\mathrm{CO}_{3}{ }^{2-}, \mathrm{NO}_{3}{ }^{-}, \mathrm{PO}_{4}{ }^{3-}, \mathrm{SO}_{4}{ }^{2-}, \mathrm{Cl}^{-}$. Temperature, $\mathrm{pH}$ was measured in field $\mathrm{pH}$ meter and Orion ion selective electrode. Electrical conductivity, fluoride, chloride, and nitrate were measured in Orion ion selective electrode(Model Meter 1119000). $\mathrm{Ca}^{2+}, \mathrm{Na}^{+}, \mathrm{K}^{+}$was measured using ELICO CL 361 Flame Photometer. TDS was measured in SYSTRONICS -TDS meter (Type no. 308). $\mathrm{HCO}_{3}{ }^{-}, \mathrm{CO}_{3}{ }^{2-}$ was measured using the titrimetric method. phosphate was measured by stannous chloride method and sulfate by the turbidimetric method. Hardness and magnesium were estimated by standard methods. ${ }^{10}$ SAR(Sodium adsorption ratio), $\mathrm{RSC}\left(\right.$ Residual sodium carbonate) and \% Na was calculated using standard formula. ${ }^{2,11-13}$

$\mathrm{SAR}=\mathrm{Na}^{+} /\left\{\left(\mathrm{Ca}^{2+}+\mathrm{Mg}^{2+}\right) \div 2\right\}^{1 / 2}$

$\% \mathrm{Na}=\left(\mathrm{Na}^{+}\right) \times 100 /\left(\mathrm{Ca}^{2+}+\mathrm{Mg}^{2+}+\mathrm{Na}^{+}+\mathrm{k}^{+}\right)$

$\mathrm{RSC}=\left(\mathrm{HCO}_{3}^{-}+\mathrm{CO}_{3}^{2-}\right)-\left(\mathrm{Ca}^{2+}+\mathrm{Mg}^{2+}\right)$

All the ionic concentrations are expressed in ppm.Correlation coefficients, mean and standard deviation of the chemical parameters were analyzed statistically.

\section{RESULTS AND DISCUSSION}

The summary of the obtained range of concentrations of physicochemical parameters of water samples is given in Table-1. In this table, the minimum and maximum concentration of major ions of the groundwater samples along with a statistical summary and official safe limits for drinking water are given. The classification of water samples on the basis of EC is given in Table- 2 and the classification of rampurhat II water samples based on hardness by Sawyer and Mc Carthy is given in Table-3. In Table -4 the water samples of the study area exceeding the desirable limits prescribed by WHO for domestic purposes are given. Classification of water samples based on $\% \mathrm{Na}$ are given in Table- 5 which shows that the irrigation quality of the Rampurhat II samples is excellent to good. The statistical correlation coefficient of major ions is described in Table- 6. Obtained results of physicochemical analysis of water quality parameters are given in Table-7.

Table-1: Statistical Summary of Water Sample Quality of Different Sources of Rampurhat-II Block

\begin{tabular}{|c|c|c|c|c|c|}
\hline \multirow[t]{2}{*}{ Ions } & \multicolumn{4}{|c|}{ Rampurhat-II Samples } & \multirow{2}{*}{$\begin{array}{c}\text { Max. acceptable } \\
\text { limits(WHO) }\end{array}$} \\
\hline & Min. & Max. & Mean & Std. Deviation & \\
\hline $\mathrm{Na}^{+}$ & 17.1 & 28.2 & 22.85 & 2.468 & 20 \\
\hline $\mathrm{K}^{+}$ & 0.06 & 1.4 & 1.015 & 0.352 & 20 \\
\hline $\mathrm{Ca}^{2+}$ & 48.67 & 115.8 & 75.83 & 16.165 & 75 \\
\hline $\mathrm{Mg}^{2+}$ & 4.86 & 12.1 & 8.615 & 2.39 & 50 \\
\hline $\mathrm{CO}_{3}{ }^{2-}$ & 0 & 0 & - & - & 350 \\
\hline $\mathrm{HCO}_{3}{ }^{-}$ & 200 & 286 & 245.37 & 25.85 & 384 \\
\hline
\end{tabular}


RASĀYAN J. Chem.

Vol. 10 | No. 4 |1424-1430 | October - December | 2017

\begin{tabular}{c|c|c|c|c|c}
\hline $\mathrm{SO}_{4}{ }^{2-}$ & 8.36 & 119.34 & 50.813 & 25.55 & 400 \\
\hline $\mathrm{NO}_{3}{ }^{-}$ & 0.91 & 7.15 & 4.638 & 1.97 & 10 \\
\hline $\mathrm{PO}_{4}{ }^{--}$ & 0.032 & 0.071 & 0.0485 & 0.01 & 5 \\
\hline $\mathrm{F}^{-}$ & 0.211 & 0.363 & 0.3 & 0.035 & 1.5 \\
\hline $\mathrm{Cl}^{-}$ & 10 & 15 & 11.67 & 1.816 & 250 \\
\hline $\mathrm{EC}$ & 526 & 905 & 807.37 & 74.1 & 300 \\
\hline $\mathrm{TH}$ & 110 & 151 & 132.47 & 12.38 & 500 \\
\hline $\mathrm{TDS}$ & 264 & 453 & 404.25 & 36.95 & 1000 \\
\hline $\mathrm{pH}$ & 7.2 & 7.41 & 7.323 & 0.066 & $6.5-8.5$ \\
\hline TEMP. & 27.2 & 28 & 27.6 & 0.204 & \\
\hline
\end{tabular}

EC values are expressed in $\mu \mathrm{S} / \mathrm{cm}$ and Temperature in ${ }^{0} \mathrm{C}$. Rest of the parameters are expressed in $\mathrm{mg} / \mathrm{l}$. In Rampurhat II samples the $\mathrm{pH}$ ranged from 7.2 to 7.41 indicating neutral to slightly alkaline nature which may be due to feldspar releasing sodium and calcium.For drinking water $300 \mu \mathrm{S} / \mathrm{cm}$ is the permissible limit for EC and it was found to be elevated in all the Rampurhat II samples.

Table-2: Classification of All Groundwater Samples Based on Electrical Conductivity (WHO) for Agricultural Purposes

\begin{tabular}{c|c|c}
\hline $\mathrm{EC}(\mu \mathrm{S} / \mathrm{cm})$ & Classification & No. of Rampurhat 2 sample \\
\hline$<1500$ & Permissible & 24 \\
\hline $1500-3000$ & Not permissible & Nil \\
\hline$>3000$ & Hazardous & Nil \\
\hline Total sample & & 24 \\
\hline
\end{tabular}

Among the Rampurhat II samples as the range of EC was 526- $905 \mu \mathrm{S} / \mathrm{cm}$, all are permissible for irrigation purposes.Among Rampurhat II samples the TDS value ranges from 264- $453 \mathrm{mg} / \mathrm{l}$ thus all within permissible limit. Fluoride, sulfate, phosphate, magnesium, chloride, potassium, nitrate and bicarbonate concentrations are also within permissible limit (Table-7)

Among Rampurhat II samples TH was found to be within the permissible limit(110- $151 \mathrm{mg} / \mathrm{l})$ according to $\mathrm{WHO}^{5}$. The classification of these samples according to Sawyer and Mc Carthy ${ }^{14}$ is given in Table-3 which shows that $45.84 \%$ samples of Rampurhat II block falls under moderate hard category and rest samples were soft. $\mathrm{CO}_{3}{ }^{-2}$ was not traced in any Rampurhat II sample.

Table -3: Classification of Rampurhat II Water Based On Hardness by Sawyer and Mc Carthy

\begin{tabular}{c|c|c}
\hline \multicolumn{2}{c|}{ Hardness and Water ClassCaCO} & Rampurhat II samples \\
\hline $0-75$ & Soft & 13 samples \\
\hline $75-150$ & Moderate hard & 11 samples $(78.63-115.8 \mathrm{mg} / \mathrm{l})$ \\
\hline $150-300$ & Hard & 0 samples \\
\hline$>300$ & Very hard & 0 samples \\
\hline
\end{tabular}

Table -4: Groundwater Samples of the Study Area Exceeding the Desirable Limits Prescribed by WHO For

\begin{tabular}{c|c|c|c}
\hline $\begin{array}{c}\text { Water quality } \\
\text { parameters }\end{array}$ & $\begin{array}{c}\text { WHO 1997, } \\
\text { desirable limits }\end{array}$ & $\begin{array}{c}\text { No. of Rampurhat II } \\
\text { samples exceeding } \\
\text { desirable limits }\end{array}$ & Undesirable effects \\
\hline $\mathrm{pH}$ & $6.5-8.5$ & Nil & Taste \\
\hline $\mathrm{EC}(\mu \mathrm{S} / \mathrm{cm})$ & 300 & $19 \mathrm{TW}, 5 \mathrm{BW}$ & Gastrointestinal irritation \\
\hline $\mathrm{TDS}(\mathrm{mg} / \mathrm{l})$ & 500 & Nil & Elevated blood pressure \\
\hline $\mathrm{TH}(\mathrm{mg} / \mathrm{l})$ & 500 & Nil & Bitter taste \\
\hline $\mathrm{Na}^{+}(\mathrm{mg} / \mathrm{l})$ & 20 & $17 \mathrm{TW}, 5 \mathrm{BW}$ & Scale formation \\
\hline $\mathrm{K}^{+}(\mathrm{mg} / \mathrm{l})$ & 20 & Nil & 9TW, 2BW \\
\hline $\mathrm{Ca}^{+}(\mathrm{mg} / \mathrm{l})$ & 75 & \multicolumn{2}{c}{}
\end{tabular}


RASĀYAN J. Chem.

Vol. 10 | No. 4 |1424-1430 | October - December | 2017

\begin{tabular}{c|c|c|c}
\hline $\mathrm{Mg}^{+}(\mathrm{mg} / \mathrm{l})$ & 50 & Nil & \\
\hline $\mathrm{CO}_{3}^{-2}(\mathrm{mg} / \mathrm{l})$ & 350 & Nil & \\
\hline $\mathrm{HCO}_{3}^{-}(\mathrm{mg} / \mathrm{l})$ & 384 & Nil & Laxative effects \\
\hline $\mathrm{SO}_{4}^{-2}(\mathrm{mg} / \mathrm{l})$ & 400 & Nil & Blue baby \\
\hline $\mathrm{NO}_{3}{ }^{-}(\mathrm{mg} / \mathrm{l})$ & 10 & Nil & Fluorosis \\
\hline $\mathrm{PO}_{4}^{-}(\mathrm{mg} / \mathrm{l})$ & 5 & Nil & Salty taste \\
\hline $\mathrm{F}^{-}(\mathrm{mg} / \mathrm{l})$ & 1.5 & Nil & Nil \\
\hline $\mathrm{Cl}^{-}(\mathrm{mg} / \mathrm{l})$ & 250 & &
\end{tabular}

Calcium was found to be above the permissible limit in $40 \%$ borewell samples and $47.368 \%$ tubewell samples(Table-7). $\mathrm{Na}^{+}$was found to be elevated in $100 \%$ deep tubewell and $89.47 \%$ shallow tubewell samples.

RSC. :The maximum RSC value of Rampurhat II groundwater samples was found to be 0.844 meq/l(Dunigram t11) which is less than $1.25 \mathrm{meq} / 1$ indicating no bicarbonate hazard in the study area.

SAR : The maximum SAR value was found to be 0.87( Modhupur t17) which is much below the permissible limit, indicating no sodium hazard in the study area.

Percentage Na : Table-5 shows that the irrigation quality of the Rampurhat II samples is excellent to good.

Table-5: Irrigation Quality of Rampurhat II Groundwater Based on \% Na

\begin{tabular}{c|c|c}
\hline$\% \mathrm{Na}$ & Classification & No. of Rampurhat II samples \\
\hline$<20$ & Excellent & $6(1 \mathrm{BW}, 5 \mathrm{TW})$ \\
\hline $20-40$ & Good & 0 \\
\hline $40-60$ & Permissible & 0 \\
\hline $60-80$ & Doubtful & 0 \\
\hline$>80$ & Unsuitable & \\
\hline
\end{tabular}

Table -6: Correlation Coefficients of the Chemical Parameters of Groundwater Samples of Rampurhat II Block

\begin{tabular}{|c|c|c|c|c|c|c|c|c|c|c|c|c|c|c|}
\hline & $\mathrm{pH}$ & EC & TDS & $\mathrm{F}^{-}$ & $\mathrm{TH}$ & $\mathrm{NO}_{3}^{-}$ & $\mathrm{SO}_{4}^{2-}$ & $\mathrm{PO}_{4}{ }^{3-}$ & $\mathrm{Ca}^{2+}$ & $\mathrm{Na}^{+}$ & $\mathrm{K}^{+}$ & $\mathrm{Mg}^{2+}$ & $\mathrm{Cl}^{-}$ & $\mathrm{HCO}_{3}$ \\
\hline $\mathrm{pH}$ & 1 & 0.211 & 0.213 & -0.3 & -0.02 & 0.085 & 0.581 & 0.112 & 0.558 & -0.21 & -0.114 & -0.184 & -0.072 & 0.257 \\
\hline $\mathrm{EC}$ & & 1 & 0.99 & -0.02 & 0.05 & 0.078 & 0.151 & 0.06 & 0.14 & -0.35 & -0.48 & 0.05 & 0.13 & 0.01 \\
\hline TDS & & & 1 & -0.02 & 0.049 & 0.078 & 0.149 & 0.064 & 0.138 & -0.355 & -0.477 & 0.052 & 0.125 & 0.012 \\
\hline $\mathrm{F}^{-}$ & & & & 1 & -0.26 & -0.057 & -0.397 & -0.184 & -0.328 & 0.075 & -0.177 & -0.2 & -0.255 & -0.255 \\
\hline $\mathrm{TH}$ & & & & & 1 & 0.035 & 0.25 & 0.194 & 0.22 & -0.23 & -0.24 & 0.79 & 0.243 & 0.28 \\
\hline $\mathrm{NO}_{3}^{-}$ & & & & & & 1 & -0.153 & 0.248 & -0.029 & -0.316 & -0.167 & -0.065 & 0.21 & -0.105 \\
\hline $\mathrm{SO}_{4}{ }^{2-}$ & & & & & & & 1 & -0.069 & 0.864 & -0.278 & -0.368 & 0.183 & -0.008 & 0.219 \\
\hline $\mathrm{PO}_{4}{ }^{3-}$ & & & & & & & & 1 & 0.09 & -0.168 & -0.085 & 0.046 & -0.24 & 0.182 \\
\hline $\mathrm{Ca}^{2+}$ & & & & & & & & & 1 & -0.295 & -0.306 & -0.002 & 0.0013 & 0.001 \\
\hline $\mathrm{Na}^{+}$ & & & & & & & & & & 1 & 0.637 & -0.22 & -0.003 & 0.05 \\
\hline $\mathrm{K}^{+}$ & & & & & & & & & & & 1 & -0.213 & -0.15 & 0.078 \\
\hline $\mathrm{Mg}^{2+}$ & & & & & & & & & & & & 1 & 0.025 & 0.002 \\
\hline $\mathrm{Cl}^{-}$ & & & & & & & & & & & & & 1 & -0.126 \\
\hline $\mathrm{HCO}_{3}{ }^{-}$ & & & & & & & & & & & & & & 1 \\
\hline
\end{tabular}

Table-7: Physicochemical Analysis of Water Quality Parameters of Rampurhat-II Block

\begin{tabular}{l|c|c|c|c|c|c|c|c|c|c|c|c|c|c|c}
\hline Sample & TEMP & PH & $\mathrm{F}^{-}$ & $\mathrm{EC}$ & $\mathrm{TDS}$ & $\mathrm{Cl}^{-}$ & $\mathrm{TH}$ & $\mathrm{Mg}^{2+}$ & $\mathrm{HCO}_{3}^{-}$ & $\mathrm{SO}_{4}{ }^{2-}$ & $\mathrm{NO}_{3}^{-}$ & $\mathrm{PO}_{4}{ }^{3-}$ & $\mathrm{Ca}^{2+}$ & $\mathrm{Na}^{+}$ & $\mathrm{K}^{+}$ \\
\hline & $\left({ }^{0} \mathrm{C}\right)$ & & $(\mathrm{mg} / \mathrm{l})$ & $(\mu \mathrm{s} / \mathrm{cm})$ & $(\mathrm{mg} / \mathrm{l})$ & $(\mathrm{mg} / \mathrm{l})$ & $(\mathrm{mg} / \mathrm{l})$ & $(\mathrm{mg} / \mathrm{l})$ & $(\mathrm{mg} / \mathrm{l})$ & $(\mathrm{mg} / \mathrm{l})$ & $(\mathrm{mg} / \mathrm{l})$ & $(\mathrm{mg} / \mathrm{l})$ & $(\mathrm{mg} / \mathrm{l})$ & $(\mathrm{mg} / \mathrm{l})$ & $(\mathrm{mg} / \mathrm{l})$ \\
\hline Ka t1 & 27.8 & 7.37 & 0.287 & 526 & 264 & 11 & 130.5 & 7.91 & 240 & 65.9 & 3.04 & 0.048 & 78.66 & 24.6 & 1.4 \\
\hline Ka t2 & 27.4 & 7.25 & 0.316 & 729 & 365 & 10 & 135 & 8.1 & 265 & 61.4 & 4.65 & 0.05 & 86.95 & 22.1 & 1.2 \\
\hline Mo t3 & 27.7 & 7.31 & 0.289 & 881 & 441 & 11 & 128.7 & 9.71 & 210 & 56.8 & 5.61 & 0.061 & 66.66 & 20.5 & 1 \\
\hline Mo t4 & 27.2 & 7.36 & 0.33 & 892 & 446 & 14.5 & 131 & 8.02 & 220 & 69.56 & 4.85 & 0.041 & 78.63 & 22.1 & 0.6 \\
\hline
\end{tabular}


RASĀYAN J. Chem.

Vol. 10 | No. 4 |1424-1430 | October - December | 2017

\begin{tabular}{l|l|l|l|l|l|l|l|l|l|l|l|l|l|l|l}
\hline Mo t5 & 27.5 & 7.3 & 0.3 & 806 & 403 & 15 & 140 & 8.89 & 280 & 73.52 & 6.45 & 0.04 & 99.7 & 21.6 & 0.7 \\
\hline Mo t6 & 27.9 & 7.4 & 0.324 & 854 & 427 & 10 & 120 & 9.6 & 204 & 70.5 & 6.5 & 0.036 & 73.7 & 17.1 & 0.2 \\
\hline Mo t7 & 27.6 & 7.3 & 0.284 & 885 & 443 & 12 & 151 & 9.72 & 255 & 67.4 & 3.36 & 0.071 & 87.48 & 19 & 0.06 \\
\hline Mo t8 & 27.7 & 7.41 & 0.283 & 866 & 434 & 11.5 & 146 & 10.1 & 286 & 58.6 & 7.15 & 0.064 & 90.02 & 23.6 & 0.9 \\
\hline Mo t9 & 28 & 7.28 & 0.283 & 798 & 399 & 12 & 135 & 9.93 & 200 & 70.51 & 5.88 & 0.044 & 89.5 & 22.1 & 1 \\
\hline Du t10 & 27.5 & 7.32 & 0.319 & 816 & 409 & 10.5 & 110 & 4.9 & 220 & 28.6 & 2.91 & 0.05 & 61.02 & 24.8 & 1.4 \\
\hline Du t11 & 27.4 & 7.29 & 0.335 & 821 & 411 & 10 & 115 & 4.86 & 260 & 15.6 & 5.89 & 0.038 & 60.47 & 22.4 & 1.2 \\
\hline Du t12 & 27.5 & 7.41 & 0.309 & 848 & 425 & 10 & 128 & 6.8 & 245 & 31.6 & 6.54 & 0.07 & 71.2 & 21.6 & 1.1 \\
\hline Du t13 & 27.7 & 7.37 & 0.245 & 784 & 393 & 11 & 164 & 15.2 & 264 & 71.32 & 6.45 & 0.055 & 80.04 & 22.2 & 1.2 \\
\hline Du t14 & 27.5 & 7.23 & 0.307 & 798 & 399 & 15 & 156 & 11.6 & 220 & 8.36 & 4.94 & 0.041 & 48.67 & 20.5 & 1 \\
\hline Du t15 & 27.6 & 7.31 & 0.309 & 811 & 406 & 14.6 & 130 & 7.4 & 235 & 14.4 & 5.62 & 0.036 & 50.02 & 26.1 & 1.4 \\
\hline Modt16 & 28 & 7.46 & 0.272 & 905 & 453 & 12 & 135 & 7.9 & 280 & 119.34 & 1.24 & 0.032 & 115.8 & 22.9 & 0.9 \\
\hline Modt17 & 27.7 & 7.26 & 0.335 & 787 & 394 & 10 & 130 & 9.1 & 240 & 46.4 & 2.68 & 0.045 & 65 & 28.2 & 1 \\
\hline Modt18 & 27.7 & 7.29 & 0.363 & 751 & 376 & 10 & 125 & 6.31 & 255 & 28.9 & 6.1 & 0.056 & 70.78 & 25.3 & 1.2 \\
\hline Modt19 & 27.4 & 7.23 & 0.331 & 792 & 397 & 12 & 125 & 8.91 & 260 & 21.41 & 6.14 & 0.052 & 72.3 & 21.9 & 0.8 \\
\hline DuT1 & 27.4 & 7.2 & 0.312 & 801 & 402 & 10 & 135 & 12.1 & 225 & 31.19 & 0.91 & 0.036 & 49.9 & 26.1 & 1.2 \\
\hline DuT2 & 27.4 & 7.3 & 0.267 & 809 & 404 & 12 & 128 & 10.2 & 265 & 42.3 & 1.08 & 0.053 & 73.85 & 23.8 & 1.4 \\
\hline Du T3 & 27.5 & 7.4 & 0.349 & 817 & 409 & 10 & 136 & 8.03 & 280 & 56.4 & 1.8 & 0.046 & 89.11 & 22.1 & 1 \\
\hline Ka T4 & 27.7 & 7.35 & 0.246 & 784 & 393 & 15 & 120 & 5.04 & 220 & 48.2 & 6.11 & 0.049 & 71.66 & 25.9 & 1.1 \\
\hline KaT5 & 27.8 & 7.37 & 0.211 & 816 & 409 & 11 & 125 & 6.44 & 260 & 61.3 & 5.42 & 0.051 & 88.77 & 21.9 & 1.4 \\
\hline
\end{tabular}

$\mathrm{T}=$ borewell sample, $\mathrm{t}=$ tubewell sample; $\mathrm{Ka}=\mathrm{Kabirajpur,} \mathrm{Mo}=$ Motain, $\mathrm{Du}=$ Dunigram, Mod=Modhupur

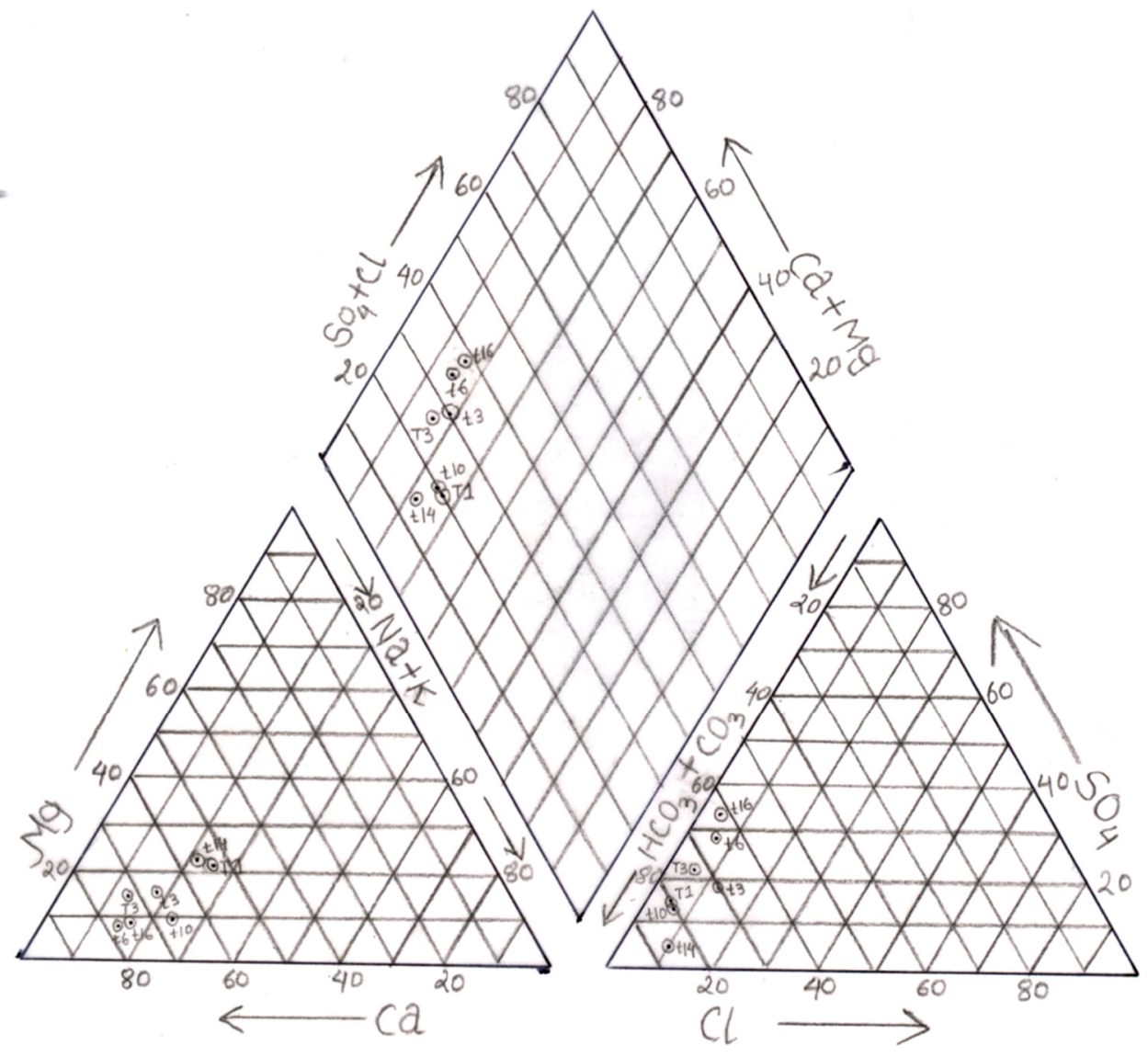

Fig.-3: Piper diagram showing the hydrogeochemical facies of Rampurhat II block 
Fig.-3 shows that in Rampurhat II block all samples are $\mathrm{SO}_{4}+\mathrm{Cl}$ type Ground water with a base exchange reaction in which the alkaline earths have been exchanged for $\mathrm{Na}^{+}$ions $\left(\mathrm{HCO}_{3}>\mathrm{Ca}^{2+}+\mathrm{Mg}^{2+}\right)$ may be referred to as base-exchanged-softened water, and those in which the $\mathrm{Na}^{+}$ions have been exchanged for the alkaline earths $\left(\mathrm{Ca}^{2+}+\mathrm{Mg}^{2+}>\mathrm{HCO}_{3}{ }^{-}\right)$may be referred to as base-exchanged-hardened water. ${ }^{15}$ In Rampurhat II groundwater samples $\mathrm{HCO}_{3}>\mathrm{Ca}^{2+}+\mathrm{Mg}^{2+}$ was observed in $20.83 \%$ samples(4 tubewells, 1 borewell sample) i.e, base-exchanged-softened water. All of these base-exchanged-softened water was observed in Dunigram village(t10, t11, t14, t15 and T1)samples. Rest $79.17 \%$ samples were baseexchanged-hardened water $\left(\mathrm{Ca}^{2+}+\mathrm{Mg}^{2+}>\mathrm{HCO}_{3}^{-}\right)$

\section{CONCLUSION}

From the obtained results it can be concluded that groundwater of the study area is suitable for irrigation but not for drinking.

\section{REFERENCES}

1. C.A. Appelo and D. Postma, Geochemistry, Groundwater and Pollution, Balkema, Rotterdam.(1993).

2. L.V. Wilcox, US Dept. Agric.Bull. 40, (1948).

3. D.W. Thorne and H.B. Peterson, Irrigated Soils, Constable and Company, London. (1949).

4. D.K. Todd, Groundwater Hydrology. Wiley,New York, 2nd edn. (1980).

5. WHO Guidelines for Drinking Water Quality,Vol. I Recommendations, World Health Organization, Geneva. (1984).

6. J.D. Hem,Study and interpretation of the chemical characteristics of natural waters, Book 2254, $3^{\text {rd }}$ edition. Scientific publishers, Jodhpur,(1991).

7. K.R. Karanth, Groundwater assessment, development and management. Tata McGraw-Hill, New Delhi(1997).

8. A. Zaporozee, Graphical interpretation of water quality data, Groundwater, 10, 32(1972) .

9. S. Chakrabarti and P. K. Patra, RJC, 9(4), 627(2016).

10. APHA, Standard method for examination of water and wastewater, American Public Health Association, $19^{\text {th }}$ edition. Washington, $D C$, (1995).

11. J.D. Hem, Study and interpretation of the chemical characteristics of natural waters, $3^{\text {rd }}$ edition. US Geological Survey Water Supply Paper,2254(1985) .

12. E.M. Eaton, Significance of carbonate in irrigation water,Soil Sci, 69, 12 (1950).

13. L.A. Richards, Diagnosis and improvement of saline and alkali soil, US Department of Agriculture, Agriculture Handbook,60(1954).

14. C.N. Sawyer, P.L. McCarthy, Chemistry of sanitary Engineers, 2nd edition. McGraw Hill, New York, 518(1967).

15. B.K. Handa Groundwater pollution in India. In: Proceedings of National Symposium on Hydrology. BHS, Publ. Univ. Roorkee, India, 34- 49(1979).

[RJC-1741/2017] 